\title{
Pro- and anti-inflammatory cytokine production by autoimmune T cells against preproinsulin in HLA-DRB1*04, DQ8 Type 1 diabetes
}

\author{
I. Durinovic-Belló ${ }^{1}$ M. Schlosser ${ }^{2} \cdot$ M. Riedl ${ }^{1}$ N. Maisel ${ }^{1} \cdot$ S. Rosinger $^{1} \cdot$ H. Kalbacher ${ }^{3}$ M. Deeg ${ }^{4}$

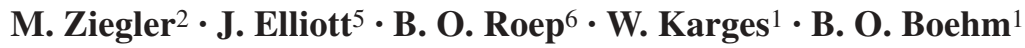 \\ ${ }^{1}$ Department of Internal Medicine I, Division of Endocrinology, University of Ulm, Ulm, Germany \\ ${ }^{2}$ Institute of Pathophysiology Karlsburg, University of Greifswald, Greifswald, Germany \\ ${ }^{3}$ Medical Scientific Center, University of Tübingen, Tübingen, Germany \\ ${ }^{4}$ Section Transplantation Immunology Medical Clinic, University of Tübingen, Tübingen, Germany \\ ${ }^{5}$ Department of Medical Microbiology and Immunology, University of Alberta, Edmonton, Canada \\ ${ }^{6}$ Department of Immunohaematology \& Blood Transfusion, Leiden University Medical Center, Leiden, The Netherlands
}

\section{Abstract}

Aims/hypothesis. Preproinsulin is a target T cell autoantigen in human Type 1 diabetes. This study analyses the phenotype and epitope recognition of preproinsulin reactive $T$ cells in subjects with a high genetic risk of diabetes [HLA-DRB1*04, DQ8 with Ab+ (auto-antibody-positive) or without islet autoantibodies (control subjects)], and in HLA-matched diabetic patients.

Methods. A preproinsulin peptide library approach was used to screen for cytokine profiles and epitope specificities in human peripheral blood lymphocytes, and $\mathrm{CD} 4{ }^{+} \mathrm{CD} 45 \mathrm{RA}^{-}$and $\mathrm{CD} 4{ }^{+} \mathrm{CD} 45 \mathrm{RA}^{+} \mathrm{T}$ cell subfractions, representing memory and naive and recently primed $\mathrm{T}$ cells respectively.

Results. In CD4+ $\mathrm{T}$ cell subsets we identified immunodominant epitopes and cytokine production patterns that differed profoundly between patients, $\mathrm{Ab}+$ subjects and non-diabetic HLA-matched control subjects. In $\mathrm{Ab}+$ subjects, a C-peptide epitope C13-29 and insulin B-chain epitope B11-27 were preferentially recognised, whereas insulin-treated Type 1 diabetic patients reacted to native insulin and B-chain epitope B1-16. In peripheral blood lymphocytes of Ab+ subjects, an increase in T helper (Th) 1 (IFN $\gamma$, IL-2) and Th2 (IL-4) cytokines was detectable, wheras in $\mathrm{CD}^{2} \mathrm{RA}^{+}$and $\mathrm{CD}^{+}$RAA ${ }^{-}$subsets, IL-4 and IL-10 phenotypes dominated, compatible with the contribution of non-CD4 cells to IFN $\gamma$ content. In insulintreated Type 1 diabetic patients, naive and recently primed $\mathrm{CD}^{+}$cells were characterised by increasd IFN $\gamma, \mathrm{TNF} \alpha$, and IL-5.

Conclusions/interpretation. Our data show that $\mathrm{T}$ cell reactivity to preproinsulin in CD45RA subsets is Th2dominant in $\mathrm{Ab}+$ subjects, challenging the Th1 paradigm in Type 1 diabetes. Characteristic immunodominant epitopes and cytokine patterns distinguish diabetic patients and Ab+ subjects from HLAmatched healthy individuals. This could prove useful in monitoring of T-cell immunity in clinical diabetes intervention trials. [Diabetologia (2004) 47:439-450]

Keywords Preproinsulin $\cdot \mathrm{T}$ cell subsets $\cdot$ Epitopes · Cytokines
Received: 10 July 2003 / Revised: 18 November 2003

Published online: 24 January 2004

(C) Springer-Verlag 2004

I. Durinovic-Belló (๘)

Department of Internal Medicine I, Division of Endocrinology, University of Ulm, Robert-Koch Str. 8, 89081 Ulm, Germany

E-mail: ivana.durinovic-bello@medizin.uni-ulm.de

Abbreviations: PPI, Preproinsulin $\cdot$ PBMC, peripheral blood mononuclear cells $\cdot$ Th, T helper cells $\cdot \mathrm{Ab}+$, autoantibodypositive $\cdot$ ICA, islet cell antibodies $\cdot$ IA-2A, islet thyrosine phosphatase $\cdot$ SI, stimulation index $\cdot$ Tr, T regulatory cells

W. Karges and B.O. Boehm contributed equally to this article
In Type 1 diabetes pancreatic beta cells expressing insulin and other autoantigens are targeted by T-cellmediated autoimmune destruction. Autoantibodies to proinsulin and insulin precede clinical disease manifestation $[1,2]$. Although $\mathrm{T}$ cells and $\mathrm{T}$ cell clones specific for insulin have been isolated from peripheral blood of patients with Type 1 diabetes and of healthy control subjects $[3,4,5,6,7,8,9]$, the degree of proliferative responses has consistently been lower than that of other candidate autoantigens. The quality of cellular autoimmunity against preproinsulin (PPI) has never been studied. 
The individual role of autoreactive $\mathrm{T}$ cells in the pathogenesis of Type 1 diabetes is unclear. Several subsets of $\mathrm{T}$ cells, in particular $\mathrm{CD}^{+}{ }^{+} \mathrm{T}$ helper $(\mathrm{Th})$ cells and recently activated cells, are increased in the peripheral blood of Type 1 diabetic patients $[5,10,11$, 12]. Yet the functional implications of these abnormalities are largely unidentified. One suggestion is that a particular subset of $\mathrm{T}$ cells could be responsible for the autoreactivity [13]. However, the relevant study also provided evidence that distinct subsets of lymphocytes can down-regulate T-cell autoreactivity, which could explain the limited extent of T-cell proliferative response to insulin.

$\mathrm{T}$ cells can exert their regulatory functions via the release of anti-inflammatory cytokines and are classified according to their cell-surface markers and cytokine patterns. Memory cells respond efficiently to recall antigens, have less stringent requirements for activation, and are able to secrete a more extensive set of cytokines than naive cells [14]. Expression of the RA isoform of CD45 (a phosphatase involved in cell signalling) and a chemokine receptor (CCR7) that controls homing to secondary lymphoid organs divides human Th cells into naive cells and two subsets of memory cells, central memory and effector memory. Naive T cells and central memory cells secrete IL-2 only, whereas effector memory cells secrete high levels of IFN $\gamma$, IL-4 and IL-5, and moderately reduced levels of IL-2. Moreover, Th cells belong to different cytokine effector classes [15]. Th1 cells, which predominantly secrete IFN $\gamma$ and TNF $\alpha$ and direct immune responses towards cell-mediated immunity, are thought to contribute to the pathogenesis of organ-specific autoimmune diseases. In contrast, Th2 cells, which preferentially produce IL-4, IL-5 and IL-10 and provide efficient help for B-cell activation and induction of humoral immune responses, are not considered to be pathogenic and could be associated with regulatory responses.

We have recently shown that a proliferative response of $\mathrm{CD}^{2} 5 \mathrm{RO}^{+}$memory Th cells to proinsulin in Type 1 diabetic patients' offspring who are positive for HLA-DRB $1 * 04$ and DQB $1 * 0302$ (DRB1*04, DQ8) is directed primarily against the C-peptide epitope C18-A1 [9]. On the epitope level, another study identified an insulin B-chain peptide (residues 9-23) as a disease-associated epitope of IFN- $\gamma$ producing mononuclear leucocytes [16].

Our study focused on overlapping synthetic peptides of PPI, a candidate target autoantigen of T-cellmediated autoimmunity in Type 1 diabetes. Our aim was to determine immunogenicity, as well as immunodominance at the peptide epitope level. Secondly, we tried to identify the nature of the cellular autoimmune response by measuring Th1 and Th2 cytokines in peripheral blood mononuclear cells (PBMC) and two distinct subsets of $\mathrm{T}$ cells separated on the basis of their surface expression of CD45 isotypes. Earlier findings have suggested that lymphocytes expressing $\mathrm{CD}^{2} \mathrm{RA}^{+}$harbour regulatory activity [13]. Thirdly, we tested homogeneous populations of unrelated individuals selected for high-risk disease-associated DRB1*04, DQ8 haplotype in (i) healthy subjects without family history of Type 1 diabetes, (ii) autoantibody-positive $(\mathrm{Ab}+)$ subjects, and (iii) subjects with recent onset of Type 1 diabetes.

In a cross-sectional approach we mapped the naturally occurring response of the CD45RA- memory and $\mathrm{CD}_{45 \mathrm{RA}^{+}}$naive and recently primed Th-cell subsets as defined by cytokines to a peptide array of PPI. We describe distinct proliferation and cytokine patterns of Th-cell subsets primed in vivo and associated with increased genetic risk alone (control subjects) or, in combination, with autoimmunity (Ab+ subjects) or overt Type 1 diabetes (patients).

\section{Subjects and methods}

Population. A total of 35 subjects who were positive for HLADRB1*04, DQ8 were analysed (Table 1 ). The group consisted of: 11 healthy control subjects with no family history of Type 1 diabetes (median age 22 years, range 2-43 years); $12 \mathrm{Ab}+$ school children from the Karlsburg Type 1 diabetes risk study [17] and with no family history of Type 1 diabetes (median age 20 years, range 8-24 years); and 12 patients with Type 1 diabetes (median age 26 years, range $2-56$ years; median duration of insulin treatment 6 months, range 1-12 months). Of the 12 $\mathrm{Ab}+$ individuals, 9 were classified as 'high risk' subjects, as they were positive for more than one additional antibody specificity, i.e. insulin autoantibodies, antibodies against GAD or islet thyrosine phosphatase (IA-2A) and/or had a high titre of cytoplasmic islet cell antibodies (ICA, >20 JDF-U) [18, 19]. Informed consent was obtained from all individuals prior to analysis, and studies were carried out in accordance with the Declaration of Helsinki.

HLA typing of DRB $1 *$ and DQB $1 *$ alleles was done using a locus-specific PCR amplification procedure as described elsewhere [20].

Autoantibody assays. The autoantibody assays have been described in detail $[17,21]$. Briefly, GAD and IA-2A were measured by fluid-phase 125I-antigen binding assays using recombinant human GAD65 (Diamyd Diagnostics, Stockholm, Sweden) and recombinant human IA-2ic (BRAHMS Diagnostica, Berlin, Germany). Levels of GAD and IA-2A were expressed as arbitrary Karlsburg units (KU/l), derived from an in-house standard serum pool. The anti-GAD assay has a diagnostic sensitivity and specificity of $88 \%$ and $96 \%$ respectively. The anti-IA-2 assay achieved 58\% diagnostic sensitivity and $100 \%$ specificity in the 1st Diabetes Antibody Standardization Program (DASP) proficiency evaluation 2001 of the Immunology of Diabetes Society (IDS) and the Centers for Disease Control and Prevention (CDC).

Insulin autoantibodies and insulin antibodies were measured by an established microassay [22] using protein A method. The 99th percentile as cut-off was calculated from 991 healthy schoolchildren. Serum concentration of GAD and IA-2A calculated via in-house standard serum is given as Karlsburg units per litre (KU/l) and insulin autoantibodies analysed by microassay [22] are given in $\mu \mathrm{U} / \mathrm{l}$. 
Table 1. Characterisation of autoantibody positive $(\mathrm{Ab}+)$ subjects, Type 1 diabetic patients and control subjects

\begin{tabular}{|c|c|c|c|c|c|c|c|c|c|}
\hline & \multirow[t]{2}{*}{ ID } & \multirow{2}{*}{$\begin{array}{l}\text { Age } \\
\text { (years) }\end{array}$} & \multirow{2}{*}{$\begin{array}{l}\text { Type } 1 \\
\text { diabetes } \\
\text { (months) }\end{array}$} & \multicolumn{2}{|l|}{ HLA } & \multicolumn{4}{|c|}{ Antibodies } \\
\hline & & & & DRB1* & DQB1* & $\begin{array}{l}\text { ICA } \\
(\mathrm{JDFU})\end{array}$ & $\begin{array}{l}* \mathrm{IAA} / \mathrm{IA} \\
\mu \mathrm{U} / 1\end{array}$ & $\begin{array}{l}\text { GAD } \\
\text { KU/1 }\end{array}$ & $\begin{array}{l}\mathrm{IA}-2 \mathrm{~A} \\
\mathrm{KU} / 1\end{array}$ \\
\hline \multirow{9}{*}{$\begin{array}{l}\text { Ab+ subjects } \\
(n=12)\end{array}$} & 1 & 8 & NA & $04,-$ & $0302,-$ & 40 & 418 & 12 & 11 \\
\hline & 2 & 10 & NA & 04,07 & 0302,0201 & 0 & 251 & 3 & 0 \\
\hline & 3 & 10 & NA & 04,03 & 0302,0201 & 160 & 479 & 64 & 23 \\
\hline & 6 & 14 & NA & 04,04 & 0302,0301 & 0 & 32 & 31 & 0 \\
\hline & 7 & 15 & NA & 04,08 & 0302,0402 & 80 & 57 & 11 & 115 \\
\hline & 8 & 15 & NA & 04,13 & 0302,0603 & 0 & 54 & 11 & 5 \\
\hline & 9 & 17 & NA & 04,13 & 0302,0603 & 320 & 73 & 55 & 544 \\
\hline & 10 & 18 & NA & 04,04 & 0302,0301 & 80 & 12 & 33 & 6 \\
\hline & 11 & 19 & NA & 04,07 & 0302,0201 & 0 & 12 & 4 & 0 \\
\hline \multirow{10}{*}{$\begin{array}{l}\text { Type } 1 \text { diabetic } \\
\text { patients }(n=12)\end{array}$} & 15 & 14 & 4 & 0401,0301 & $0302,-$ & 0 & 8 & 1 & 1 \\
\hline & 16 & 18 & 10 & 0401,0405 & 0302,02 & 0 & 14021 & 50 & 3 \\
\hline & 17 & 22 & 1 & 0401, 0801 & 0302,0301 & 0 & 63 & 110 & 19 \\
\hline & 18 & 24 & 8 & 0402,0101 & 0302,0501 & 0 & 21 & 39 & 41 \\
\hline & 19 & 27 & 3 & 0401,0401 & 0302,0301 & 160 & 5332 & 41 & 60 \\
\hline & 20 & 28 & 11 & 0401,0301 & 0302,02 & 320 & 12389 & 127 & 2 \\
\hline & 21 & 30 & 12 & 0401,0301 & 0302,02 & 80 & 4049 & 87 & $\mathbf{5 5 0}$ \\
\hline & 22 & 31 & 1 & 0401,0701 & $0302,-$ & 0 & 59 & 5 & 0 \\
\hline & 23 & 45 & 6 & 0401,0101 & 0302,0501 & 0 & 23434 & 1 & 1 \\
\hline & 24 & 56 & 1 & 0401,1302 & 0302,0604 & 1280 & 1249 & 79 & 154 \\
\hline \multirow{4}{*}{$\begin{array}{l}\text { Control subjects } \\
(n=11)\end{array}$} & 25 & 2 & NA & 0404,1001 & 0302,0501 & 0 & -49 & 1 & 0 \\
\hline & 26 & 15 & NA & 0401,0408 & 0302,0301 & 0 & 53 & 0 & 0 \\
\hline & 34 & 43 & NA & 0401,0301 & 0302,02 & 0 & 203 & 1 & 0 \\
\hline & 35 & 20 & NA & 0404,03 & 0302,0201 & 0 & 130 & 0 & 0 \\
\hline
\end{tabular}

The numbers in bold represent positive antibody titres. ID, identity number; ICA, islet cell antibodies; *IAA, insulin autoantibodies; IA, insulin antibodies; IA2A, islet thyrosine phosphatase; KU, Karlsburg units; NA, not applicable

Islet cell antibodies were measured by indirect immunofluorescence on cryosections of human pancreas after overnight incubation at $4^{\circ} \mathrm{C}$. The detection limit was $5 \mathrm{JDF}$ units. Levels of ICA at or above $20 \mathrm{JDF}$ units were considered to be positive. The assay achieved an analytical sensitivity and specificity of $100 \%$ in the 13th ICA Workshop 1998.

Cell separation and enrichment of CD45RA- memory and CD45RA+ naive and recently primed Th cells. Peripheral blood mononuclear cells were isolated from heparinised blood by Ficoll-paque (Pharmacia, Freiburg, Germany) density centrifugation, aliquoted, and cryopreserved in liquid nitrogen until use. Enrichment of $\mathrm{CD}^{4} 5 \mathrm{RA}^{-}$memory and $\mathrm{CD}^{-} 5 \mathrm{RA}^{+}$ naive and recently primed Th cells from PBMC of all investigated persons was done in two steps using a CD4+ $4^{+}$-cell isolation kit (Miltenyi Biotec, Auburn, Calif., USA). First, CD4+ cells were enriched by depletion of all non-CD4 (CD8, CD11b, CD16, CD19, CD36 and CD56) cells. Then CD45RA- memo- ry cells were enriched by depletion of $\mathrm{CD}^{2} 4 \mathrm{RA}^{+}$cells using CD45RA MicroBeads. Positively sorted CD45RA ${ }^{+}$cells were released from the column, and CD45RA ${ }^{+}$and $\mathrm{CD}^{4} 5 \mathrm{RA}^{-}$cells were counted and adjusted to $4 \times 10^{5}$ cells per millilitre in IMDM Glutamax medium (GibcoBRL, Eggenstein, Germany). The mean purity of CD45RA ${ }^{+}$and CD45RA- cells was $96.8 \%$ and $94.7 \%$ respectively, as defined by FACS analysis, and the viability of both cell subsets was $99 \%$, as determined by tripan blue exclusion. As the CD45RA ${ }^{+}$cell population was positively sorted, it also contained the recently activated CD45RA + $\mathrm{RO}^{+}$cell population $[12,13]$. Of the total PBMC of investigated individuals an average of $12.06 \pm 6.7 \%$ were $\mathrm{CD}^{+}$cells, $69.67 \pm 16.9 \%$ were $\mathrm{CD}_{45 \mathrm{RA}^{-}}$and $38.2 \pm 16.5$ were CD45RA ${ }^{+}$ cells.

Autoantigens, peptides and control antigens. Human proinsulin (86 amino acids, aa; a kind gift of Eli Lilly, Indianapolis, Ind., USA) and insulin (51 aa; a kind gift of Aventis, Frankfurt, Ger- 
many) were tested simultaneously with 21 overlapping PPI peptides. Preproinsulin peptides were 16 to 17 amino acids long and overlapped by 12 amino acids. They were synthesised according to the primary PPI structure (GenBank accession number P01308). All antigens and peptides were highly purified and did not contain significant levels of endotoxin as determined by the Limulus lysate assay $(<0.06 \mathrm{EU} / \mathrm{ml}$ at $10 \mu \mathrm{g}$ peptide $/ \mathrm{ml})$. In each Th-cell assay, control peptide CASSSDRLGNQPQHF (T-cell antigen receptor peptide, see [23]), tetanus toxoid (Connaught Laboratories, Toronto, Ont, Canada) and phytohaemagglutinin M (Difco, Michigan, Ill., USA) were included.

Proliferation assay. The proliferation assay, which has been described [23], was modified for enriched Th-cell subpopulations and is currently being evaluated in our laboratory as part of the ongoing Second International Workshop for Standardization of T-cell assays [24]. Briefly, microtitre plates were prepared as follows and stored at $-80^{\circ} \mathrm{C}$ until use. Autoantigens, peptides or control antigens $(50 \mu \mathrm{l}$ per well $)$ were plated in triplicate. Proinsulin and insulin were used at $10 \mu \mathrm{g} / \mathrm{ml}$, PPI peptides at $5 \mu \mathrm{g} / \mathrm{ml}$, tetanus toxoid at $1 \mu \mathrm{g} / \mathrm{ml}$, control peptide at $5 \mu \mathrm{g} / \mathrm{ml}$, and phytohaemagglutinin $\mathrm{M}$ at a concentration of $0.01 \%$. On the day of the test, plates were thawed and $100 \mu \mathrm{l}$ of autologous PBMC were plated per well as antigen-presenting cells (irradiated 40 Gy). Finally, $100 \mu \mathrm{l}$ of CD45RA- memory cells or $\mathrm{CD}_{45 \mathrm{RA}^{+}}$naive and recently primed cells were added per well and incubated for 5 days at $37^{\circ} \mathrm{C}$ and $6 \% \mathrm{CO}_{2}$. Then ${ }^{3} \mathrm{HTdR}$ was added and after $16 \mathrm{~h}$ the cells were harvested. The results are expressed as stimulation index (SI), i.e. counts per min in the presence of antigen, divided by counts per min in the medium alone. The intra-assay coefficient variation of SIs on five replicate tests was $28 \%$, and the inter-assay variation on two replicate tests was $18 \%$.

Cytokine assay. To measure the level of TNF $\alpha$, IFN $\gamma$, IL-2, IL-4, IL-5 and IL-10 secreted after stimulation with proinsulin, insulin and 21 overlapping PPI peptides, $175 \mu$ of supernatant was taken from each well on day 5 of culture followed by addition of ${ }^{3} \mathrm{H}-\mathrm{TdR}$. Supernatants of replicate cultures were pooled and stored at $-20^{\circ} \mathrm{C}$ until assay. They were analysed according to the manufacturer's instructions, using an antigencapture ELISA from PharMingen (San Diego, Calif., USA). Detection limits for each cytokine were $19.5 \mathrm{pg} / \mathrm{ml}$ for TNF $\alpha$, $34.2 \mathrm{pg} / \mathrm{ml}$ for IFN $\gamma, 9.8 \mathrm{pg} / \mathrm{ml}$ for IL-2, $19.5 \mathrm{pg} / \mathrm{ml}$ for IL-4, $48.8 \mathrm{pg} / \mathrm{ml}$ for IL-5 and $4.9 \mathrm{pg} / \mathrm{ml}$ for IL-10. Heterophile antibodies (e.g. Ig cross-reactive substances) from human serum samples which have been reported to interfere with cytokine assays [25] were excluded in our cell culture medium (contains $7 \%$ human serum pool) by measuring anti-Fc receptor antibodies (below the cut-off of $0.7 \mathrm{U} / \mathrm{ml}$ ) and by control cytokine measurements using the correct capture and detection reagent pairs (e.g. anti-IL-4 and anti-IL-4) in comparison to the signal detected with antibody mismatch pairs (e.g. anti-IL-4 and antiTNF $\alpha$, capture and detection respectively), which gave a signal below the detection limit of $19.5 \mathrm{pg} / \mathrm{ml}$. Quantification of spontaneous cytokine release was done by incubating the cells of each individual under the same conditions as PPI peptides in the absence of antigen. Positive cytokine responses were defined as two adjacent peptide (antigen)-stimulated wells, which gave responses greater than the mean $+2 \mathrm{SD}$ of unstimulated wells. The amount of secreted cytokines was expressed in $\mathrm{pg} / \mathrm{ml}$.

Statistical analysis. Proliferation data were analysed using the SPSS software package (SPSS Software, Munich, Germany). The non-parametric Mann-Whitney U test for unpaired observations, with an appropriate adjustment to the significance level for multiple comparisons, was used. Cytokine data were analysed by general linear models, which allow for unbalanced and dependent data, using the statistical software SAS 8.2 (SAS, Heidelberg, Germany) (compound symmetry was assumed for the structure of the covariance matrix). The results section presents $p$ values and differences of model-predicted means with $95 \%$ CIs. The CIs were adjusted for multiple comparisons (Tuker-Kramer adjustment). Differences in the prevalence of Th-cell proliferation and changes in cytokine levels between the groups were compared by Fisher's exact test. Differences were considered to be significant at a $p$ value of less than 0.05 .

\section{Results}

Proliferative responses in PBMC and Th-cell subsets. In unsorted PBMC proliferative responses to either proinsulin, insulin or PPI peptides were low and did not differ between the groups tested (Fig. 1). After sorting of PBMC into two Th-cell subsets, CD45RA ${ }^{+}$ naive and recently primed cells and CD45RA ${ }^{-}$memory cells, greater proliferation was observed, especially in subjects with islet autoimmunity (patients and $\mathrm{Ab}+$ subjects).

In naive and recently primed cells Type 1 diabetic patients displayed a different reactivity pattern to that of non-diabetic $\mathrm{Ab}+$ and control subjects. They reacted more strongly than both other groups to native insulin and proinsulin $(9 / 24,38 \%$ vs $1 / 24,4 \%$ and $4 / 22,18 \%$ respectively, $p<0.008)$ and to PPI peptides (39/166, $23 \%$ vs $25 / 252,10 \%$ and $19 / 197,10 \%$ respectively, $p<0.0003)$. Proliferative responses were distributed over the whole PPI molecule with high variability in individual subjects. Peptide B1-16 was most common. Frequency and magnitude of the response to this peptide was higher in patients than in $\mathrm{Ab}+$ and control subjects $(p<0.0002$ and $p<0.03$ respectively). In $\mathrm{Ab}+$ subjects the responses to $\mathrm{C} 13-29$ were more frequent in naive and recently primed cells than in the other two groups $(5 / 12$ vs $0 / 23$ respectively, $p<0.005)$.

Compared to control subjects, memory cell proliferative response of $\mathrm{Ab}+$ subjects and Type 1 diabetic patients was more frequent to proinsulin and insulin (0/11 vs $12 / 24$ respectively, $p<0.003)$ and to PPI peptides (11/197 vs $81 / 418$ respectively, $p<0.000003)$. In $\mathrm{Ab}+$ subjects and Type 1 diabetic patients the responses were randomly distributed over the whole PPI molecule. However, in $\mathrm{Ab}+$ subjects two peptides displayed higher responses, B11-27 and C13-29. Frequency and magnitude of the response to peptides B11-27 and C13-29 were strongest in Ab+ subjects compared to both other groups $(p<0.0003$ and $p<0.03$, and $p<0.007$ and $p<0.03$ respectively). Peptide C13-29 overlaps peptide C18-A1, which was previously identified as a major epitope of DRB $1 * 0401$ transgenic mice and DRB $1 * 0401$ positive human subjects by 12 amino acids. Peptide B11-27 largely overlaps B9-23, which was previously identified as an immunodominant epitope in mice and humans. 


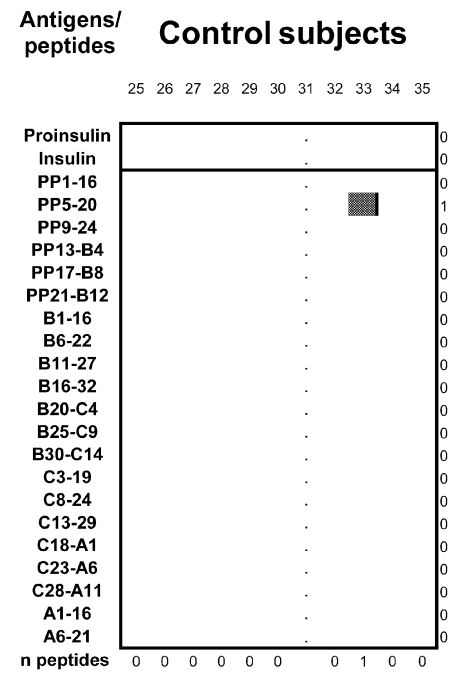

Ab+ subjects

$\begin{array}{lllllllllllll}1 & 2 & 3 & 4 & 5 & 6 & 7 & 8 & 9 & 10 & 11 & 12\end{array}$

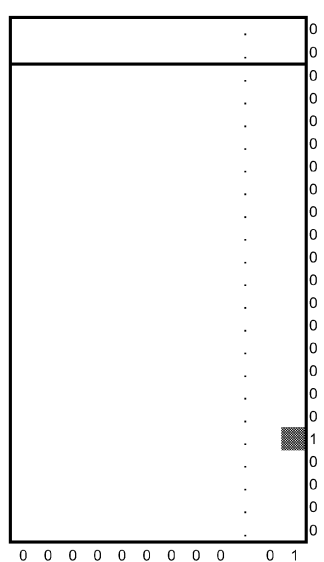

Type 1 diabetic patients

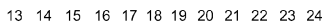

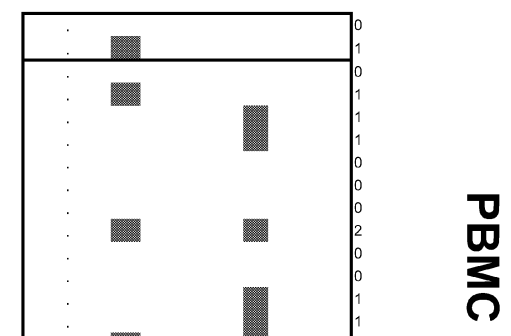

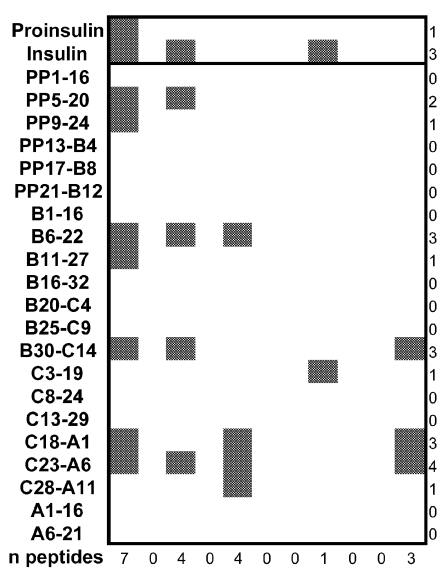
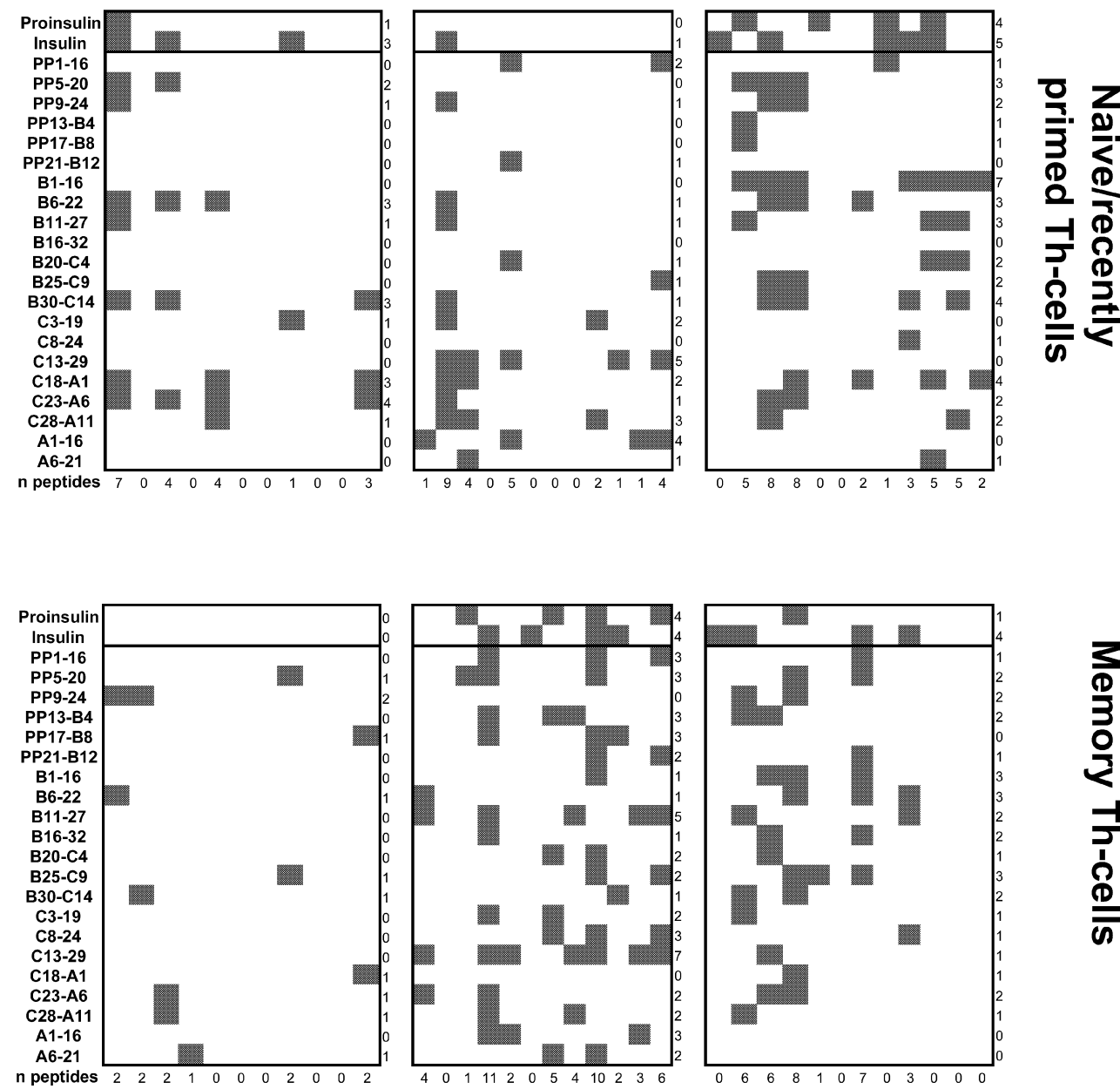

$\frac{3}{10}$
$\frac{1}{3}$
$\frac{1}{2}$
$\frac{1}{0}$
$\frac{0}{0}$

Fig. 1. Proliferative responses to proinsulin, insulin and 21 overlapping PPI peptides in PBMC and in the Th-cell subsets naive and recently primed cells $\left(\mathrm{CD} 45 \mathrm{RA}^{+}\right)$and memory cells (CD45RA-). Only responses $\mathrm{SI} \geq 2.5$ are shown (grey bars). The magnitude of responses between three investigated groups of subjects was compared with the Mann-Whitney U test and

prevalence of responses with the Fisher's exact test. PBMC of patient no. 14, Ab+ subject no. 10 and control subject no. 31 were not tested. The symbol - means data not shown. $A b+$ autoantibody-positive, $P P I$ preproinsulin, $P B M C$ peripheral blood mononuclear cells, $T h$ T helper, SI stimulation index 


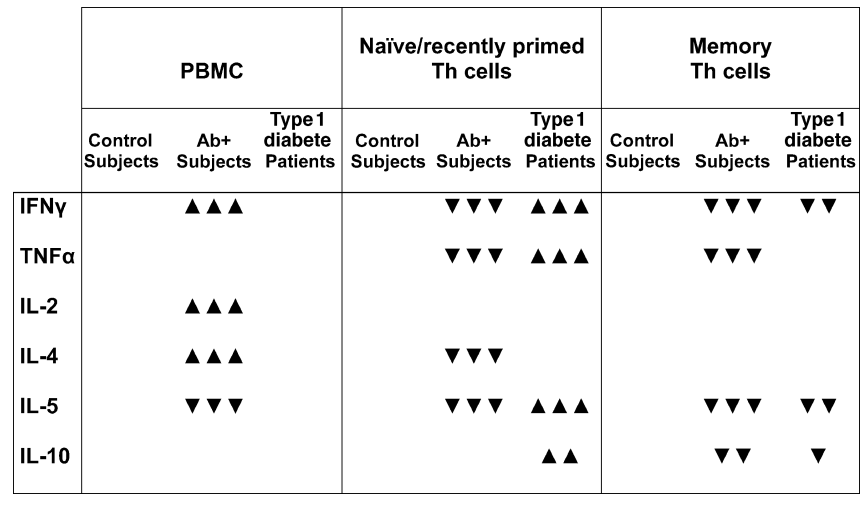

Fig. 2. Distribution of cytokines in response to 21 overlapping preproinsulin peptides in unsorted PBMC and two CD4+ $\mathrm{T}$ cell subsets representing naive and recently primed cells $\left(\mathrm{CD} 45 \mathrm{RA}^{+}\right)$and memory cells $\left(\mathrm{CD}^{4} 5 \mathrm{RA}^{-}\right)$in non-diabetic control subjects, $\mathrm{Ab}+$ subjects and recent onset Type 1 diabetes patients. Increased: $\boldsymbol{\Delta} \mathbf{\Delta}=p<0.005, \boldsymbol{\Delta} \mathbf{\Delta} \mathbf{\Delta}=p<0.0005$. Decreased: $\boldsymbol{\nabla} \nabla \boldsymbol{\nabla}=p<0.0005, \quad \boldsymbol{\nabla}=p<0.005, \quad \boldsymbol{\nabla}=p<0.05 . \quad A b+$ autoantibody-positive, $P B M C$ peripheral blood mononuclear cells, Th T helper

Recognition of multiple peptides $(>2)$ was more pronounced in memory cells of $\mathrm{Ab}+$ subjects than in control subjects $(p<0.006)$, whereas no difference between the three groups was found in naive and recently activated cells.

Cytokine responses in PBMC and Th-cell subsets. Cytokine analysis of PBMC and two Th-cell subsets showed that pro-inflammatory and anti-inflammatory cytokines (Th1/Th2) are produced in response to PPI peptides. However, differences in quality and quantity of the responses were observed in the three groups of subjects.

In $\mathrm{Ab}+$ subjects the highest levels of cytokine responses, compared to the other two groups (Fig. 2), were present in PBMC after stimulation with PPI peptides characterised by an increase in production of IFN $\gamma \quad(p<0.0005)$, IL-2 $(p<0.0005)$ and IL-4 $(p<0.0005)$. The simultaneous increase in IFN $\gamma$ and IL-4 in Ab+ subjects correlated strongly with the increased number of PPI peptides recognised per subject $(r=0.8, p<0.003)$. As a result, Th0 phenotype of cytokine responses to PPI peptides was higher in $\mathrm{Ab}+$ individuals than in patients $(42 / 252,17 \%$ vs $17 / 252,7 \%$ respectively, $p<0.005)$ and control subjects $(17 / 231$, $7 \%, p<0.005$ ) (Fig. 3). Cytokine responses to native insulin were characterised by higher IFN $\gamma$ levels than in control subjects $(p<0.02)$.

After sorting of PBMC into naive and recently primed or memory Th-cell subsets, marked differences were observed in $\mathrm{Ab}+$ subjects, compared to those of patients and control subjects (Fig. 2), with regard to Th1 type cytokines. IFN $\gamma$ and TNF $\alpha$ were decreased in both cell subsets $(p<0.0001)$ (Fig. 2). Hence, Th2 and $\mathrm{T}$ regulatory (Tr) phenotypes, charac- terised by IL-4 and IL-10, predominated in cell subsets of $A b+$ subjects (Fig. 3). In memory cells of $A b+$ subjects $\mathrm{Th} 2 / \mathrm{Tr}$ responses to PPI peptides were greater than in patients and control subjects $(p<0.0005$ and $p<0.005$, Fig. 3).

In $\mathrm{Ab}+$ subjects IL-5 concentrations were consistently lower in PBMC $(p<0.0005)$ and in both Th-cell subsets $(p<0.0001)$ than in the other two groups (Fig. 2).

In insulin-treated Type 1 diabetic patients naive and recently activated cells had increased production of IFN $\gamma(p<0.0005)$, TNF $\alpha(p<0.0005)$, IL-5 $(p<0.0005)$ and IL-10 $(p<0.005)$ compared with control and Ab+ subjects (Fig. 2). Consequently, mainly Th0 cytokine response phenotype to PPI peptides evolved. This was more frequent in patients than in $\mathrm{Ab}+$ and control subjects $(p<0.0005)$ (Fig. 3). In memory cells of the patients $\mathrm{Th} 2 / \mathrm{Tr}$ responses were more frequent than in control subjects $(p<0.0005)$ and Th1 and Th0 responses were more frequent than in $\mathrm{Ab}+$ subjects $(p<0.005$ and $p<0.0005)$.

An increased response of IFN $\gamma(p<0.005)$ accompanied by a similarly increased production of IL-10 $(p<0.005)$ in memory Th cells in control subjects led to mainly Th0 cytokine response phenotype. In PBMC and naive and recently activated cells of the control subjects $\mathrm{Th} 2 / \mathrm{Tr}$ responses predominated (Fig. 2, Fig. 3).

The three groups of subjects showed no difference in spontaneous cytokine release in PBMC or any of the cell subsets for any of the cytokines tested.

Quality of proliferative and cytokine responses to commonly recognised PPI epitopes. Although proliferative responses to PPI peptides were generally randomly distributed over the molecule in Th-cell subsets of $\mathrm{Ab}+$ subjects, three peptides showed increased proliferation (Fig. 1): (i) peptide C13-29 in both cell subsets; (ii) peptide B11-27 in memory cells of Ab+ subjects; and (iii) peptide B1-16 in naive and recently primed cells of the patients.

No obvious association of specific cytokine patterns with increased proliferation was found (Fig. 4). However, increased proliferation in $\mathrm{Ab}+$ subjects in response to peptide C13-29 was predominantly associated with Th2/Tr-type response and decreased levels of IFN $\gamma$ (memory cells: $p<0.006$; naive and recently primed cells: $p<0.02$ ) and IL-5 (memory cells:

Fig. 3. Cytokine phenotype of T-cell responses to proinsulin, insulin and single preproinsulin peptides, compared in PBMC and two Th-cell subsets representing naive and recently primed cells $\left(\mathrm{CD} 45 \mathrm{RA}^{+}\right)$and memory cells $\left(\mathrm{CD} 45 \mathrm{RA}^{-}\right)$of non-diabetic control subjects, Ab+ subjects, and Type 1 diabetes patients. black Th1 (IFN $\gamma$ ), light grey Th2/Tr (IL-4 and/or IL-10), dark grey Th0 (IFN $\gamma$ and IL-4 and/or IL-10). $A b+$ autoantibody-positive, $P B M C$ peripheral blood mononuclear cells, Th T helper 
Control subjects Antigens/
peptides
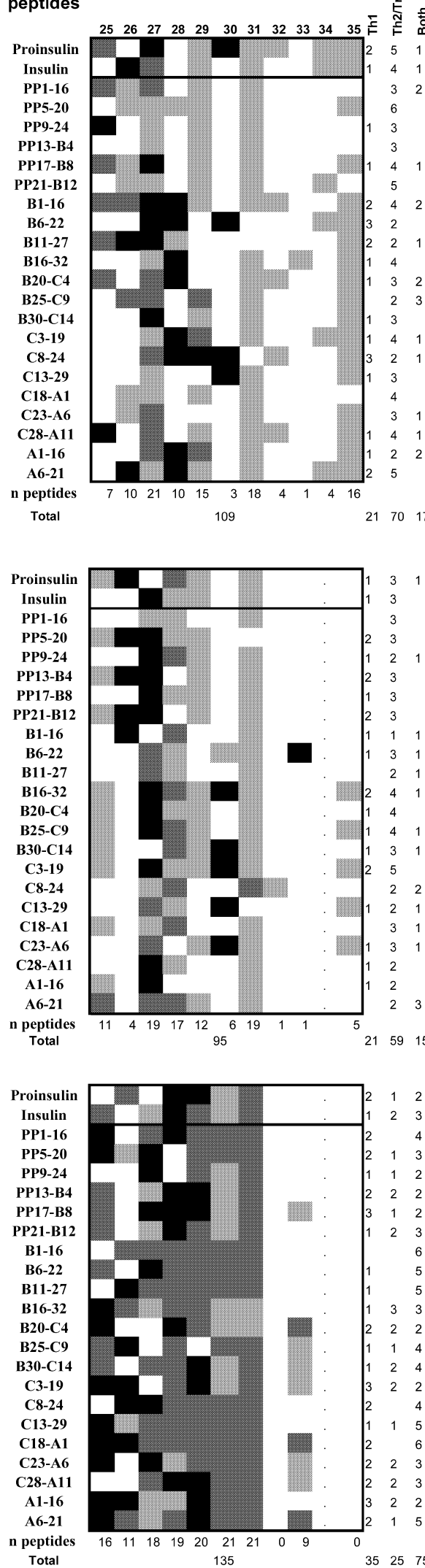

$A b+$ subjects

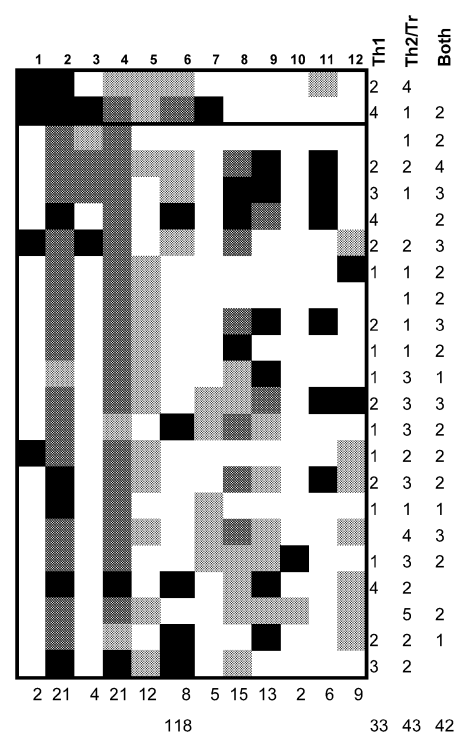

Type1 diabetic patients nsujects

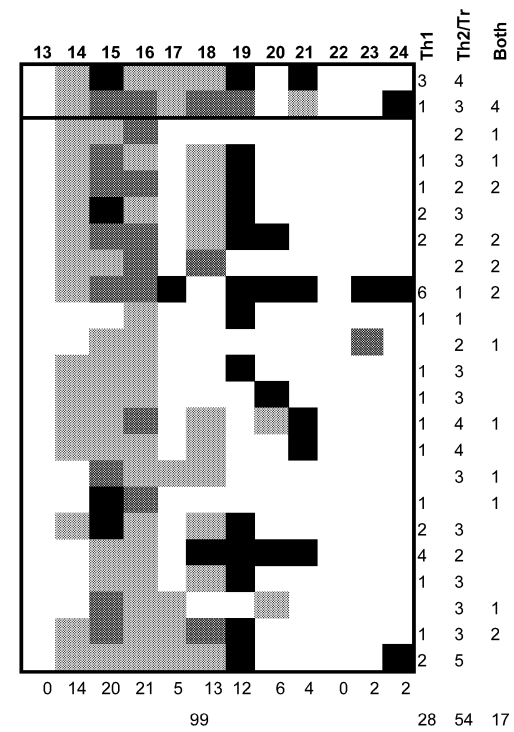

뭄
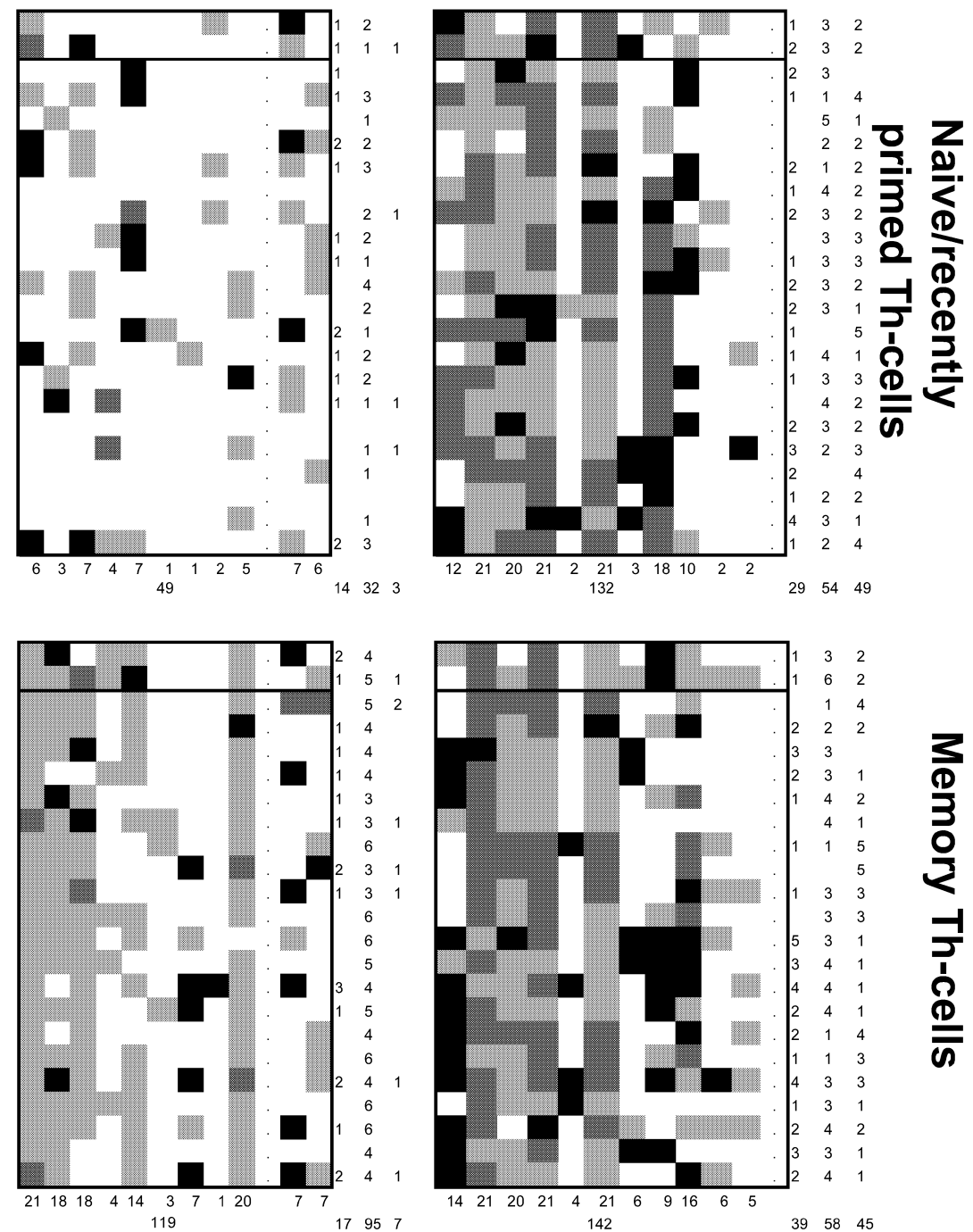


\section{$\mathrm{CD}^{+}{ }^{+} \mathrm{CD} 45 \mathrm{RA}^{+}$}

a

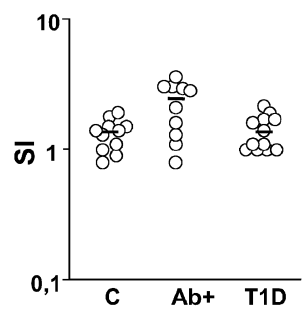

b

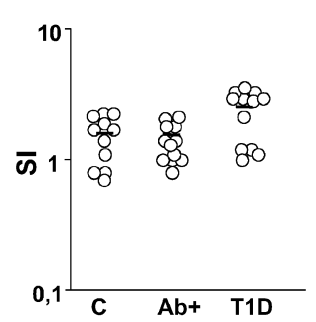

C

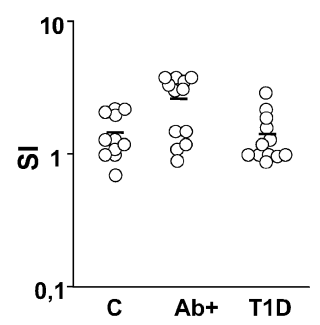

d

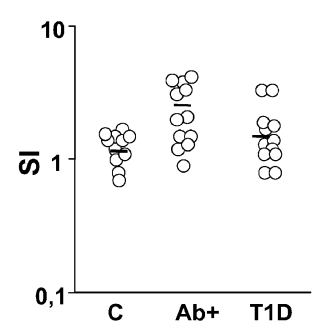

C13-29

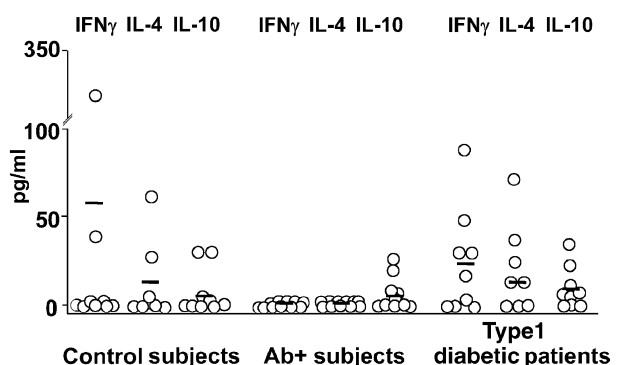

B1-16
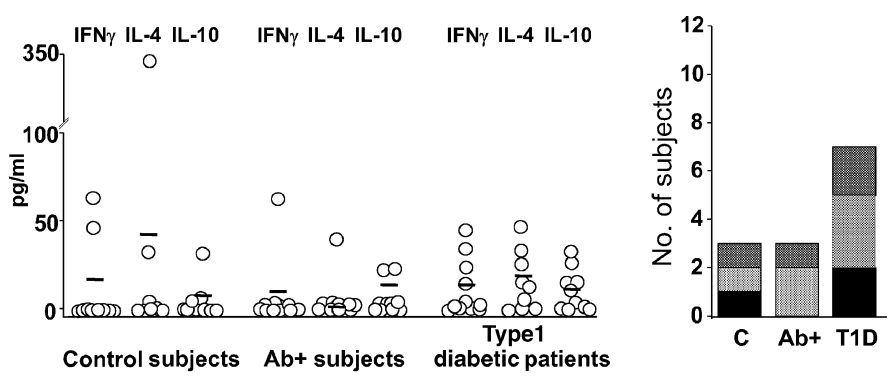

\section{$\mathrm{CD}^{+}{ }^{\mathrm{CD}} 45 \mathrm{RA}^{-}$}

C13-29
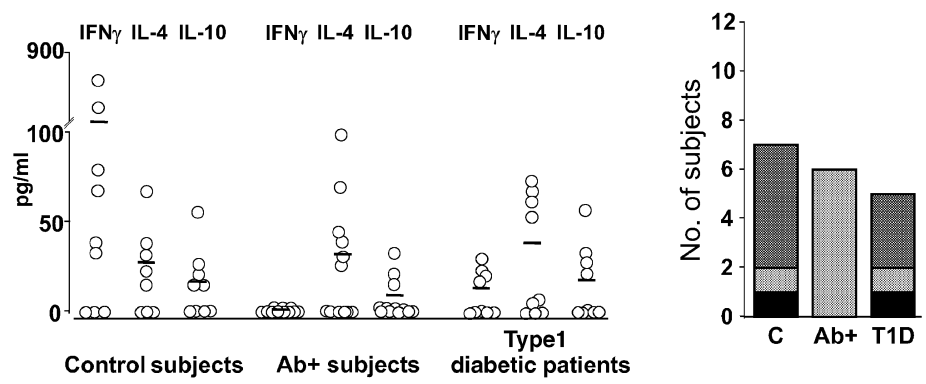

B11-27

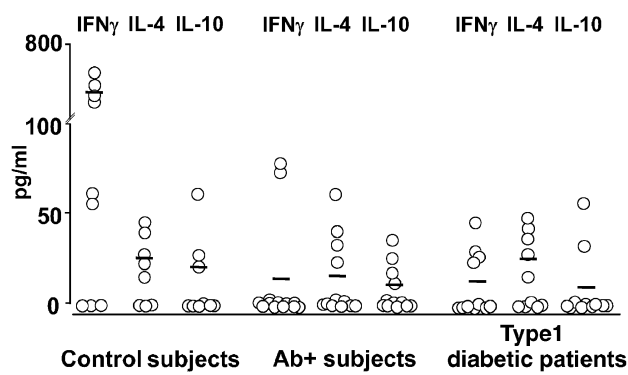


$p<0.02$; naive and recently primed cells: $p<0.002)$ in both Th-cell subsets (Fig. $4 \mathrm{a}, \mathrm{c}$ ). Increased proliferation in response to peptide B11-27 in memory cells of $\mathrm{Ab}+$ subjects and to peptide B1-16 in naive and recently primed cells of the patients was associated with all three types of Th response. No difference in cytokine levels between the three groups of subjects was seen (Fig. 4b, d).

\section{Discussion}

We tested the hypothesis that, due to in vivo priming during the spontaneous autoimmune response, differences in the quality and quantity of T-cell responses occur in Type 1 diabetic patients with islet-cell autoimmunity, when compared with healthy HLA-matched control subjects. If autoreactive PPI epitope-specific $\mathrm{T}$ cells are involved in the development of Type 1 diabetes, they should show increased proliferation and an activated peripheral memory cell differentiation state characterised by high IFN $\gamma$, IL-4 and IL-5 production [14]. On the other hand, in control subjects, cells are expected to be predominantly of the immunoregulatory $(\operatorname{Tr} 1)$ or suppressive phenotype, which proliferate poorly and secrete high levels of IL-10 and considerable levels of TGF $\beta$ and IL-5 [26] or IL-4 and IL-10 [27].

In animal models of Type 1 diabetes it has been suggested that pro-inflammatory cytokine responses (IFN $\gamma$ ) drive disease progression and anti-inflammatory Th2 responses (IL-4, IL-10) drive disease protection $[15,28]$. Yet, the multiple pro- and anti-inflammatory effects of most cytokines, depending on the target cell type (PBMC, i.e. pancreatic islets), disease, and many other factors, should be taken into consideration. To detect the entire in vivo primed PPI-specific repertoire we used overlapping PPI peptides (16 amino acids long) that can bind directly to major histocompatibility complex class II molecules, and hence favour the detection of CD4 cells. To be able to compare T-cell responses to the single peptide epitopes we strictly selected all three groups of subjects for the expression of the DRB $1 * 04, \mathrm{DQ} 8$ haplotype associated with high risk for Type 1 diabetes.

4 Fig. 4a-d. Comparison of the quality of proliferative response, and level and phenotype of the cytokine response, to commonly recognised preproinsulin epitopes in three groups of subjects. The left, middle and right-hand elements show stimulation index (SI), level in $\mathrm{pg} / \mathrm{ml}$ and phenotype respectively. Reactivity of naive and recently primed Th cells $\left(\mathrm{CD}^{4} 4 \mathrm{RA}^{+}\right)$ is shown (a) to C-peptide epitope C13-29, and (b) to insulin B-chain epitope B1-16. Reactivity of memory Th cells (CD45RA-) is shown (c) to C-peptide epitope C13-29 and (d) to insulin B-chain epitope B11-27. black Th1 (IFN $\gamma)$, light grey $\mathrm{Th} 2 / \mathrm{Tr}$ (IL-4 and/or IL-10), dark grey Th0 (IFN $\gamma$ and IL-4 and/or IL-10). $A b+$ autoantibody-positive, $C$ control subjects, T1D Type 1 diabetic patients
In previous studies using unsorted PBMC of randomly selected diabetic patients or individuals at risk and non-diabetic control subjects no differences were found in the extent of immunogenicity of proinsulin, insulin or overlapping peptides $[4,6,29]$. We, however, sorted PBMC, consisting of many different cell types, into two clearly defined Th-cell subsets, memory $\left(\mathrm{CD} 45 \mathrm{RA}^{-}\right)$and naive and recently primed $\left(\mathrm{CD}_{\left.45 \mathrm{RA}^{+}\right)}\right.$cells. This enabled us to detect responses which were previously undetectable due to the contribution of numerous cell types in the periphery. Our study showed increased proliferation and preferential recognition of three peptide epitopes in autoimmune subjects, while $\mathrm{Ab}+$ subjects reacted to $\mathrm{C} 13-29$ (both cell subsets) and to B11-27 (memory cells), and patients reacted to B1-16 (naive and recently primed cells). Increased proliferation in response to peptide C13-29 was associated in Th-cell subsets of Ab+ subjects with decreased Th1 cytokine levels and predominantly $\mathrm{Th} 2 / \mathrm{Tr}$-type responses. Interestingly, peptide C13-29 overlaps C18-A1 by 12 amino acids, which was previously identified as immunodominant epitope in DRB1*04, DQB1*0302-positive subjects with and without autoimmunity [9] and in DRB $1 * 0401$ transgenic mice [30], and peptide B11-27 largely overlaps B9-23, which was previously identified as immunodominant epitope in mice [31] and man [9, 16]. Moreover, a T-cell clone specific for peptide B11-27 has been isolated from recent onset Type 1 diabetic patients using whole insulin as an antigenic stimulus [7]. Proinsulin B-cell epitopes have also been located in C-peptide as well as in signal peptide regions, implying strong immunogenicity of these regions in individuals with a genetic background associated with Type 1 diabetes [32, 33]. Peptides C13-29 and B11-27 have high binding affinity to DRB1*0401 and DQ8 respectively $[16,34,35]$.

Cytokine responses of Type 1 diabetic patients to peptide B1-16 were higher for IFN $\gamma$, IL-4 and IL-10 than in the other two groups. Interestingly, insulin B-cell epitope B1-3 is situated in the same overlapping region [36] and anti-insulin antibodies appear predominantly in DRB1*04-positive subjects $[37,38]$. This implies a strong immunogenicity of this region in individuals with a disease-associated genetic background. As in our study healthy control subjects were completely matched for HLA-DRB $1 * 04$, DQ8 haplotype with $\mathrm{Ab}+$ subjects and Type 1 diabetic patients, our results indicate that reactivity to these peptides is associated with islet autoimmunity rather than genetic predisposition to Type 1 diabetes. This is consistent with another study [13], which found the most pronounced immune reactivity to insulin in recently activated cells of Type 1 diabetic patients. Our study provides further evidence for the presence of PPI peptide-specific autoimmunity in lymphocyte subsets in humans.

The degree of determinant spreading, i.e. the number of peptides recognised per subject, also distin- 
guished the groups. Response to multiple epitopes $(>2)$ was more frequent in memory cells of the two groups of subjects with Type 1 diabetes autoimmunity than in the HLA-matched control subjects. It has been shown that inter-molecular epitope spreading of T-cell responses to various beta-cell antigens, as well as intra-molecular epitope spreading to different epitopes of the proinsulin molecule, is a common feature of disease progression in Type 1 diabetes [4, 9, 39]. Our results added to these findings by showing that cells responsible for intra-molecular PPI epitope spreading are found within the memory Th-cell subset. This indicates that the response was already primed in vivo in the course of Type 1 diabetes autoimmunity.

Our study showed that Th1 and Th2/Tr cytokines were produced in response to PPI. However, the quality and pattern of cytokine levels in PBMC and both Th-cell subsets differed considerably between subjects with islet autoimmunity and control subjects. The $\mathrm{PBMC}$ of $\mathrm{Ab}+$ subjects had an increased overall cytokine level, which contributed to the dominance of the Th0 phenotype of the PPI peptide response. In sorted Th-cell subsets IL-4 and IL-10 responses predominated. This was caused by a selective decrease in IFN $\gamma$ and TNF $\alpha$, which was especially pronounced in memory cells. A decrease in the level of these cytokines after sorting into two Th-cell subsets provides additional evidence that other cell types, which are present in PBMC and have been depleted by cell sorting, are actively involved in the autoimmune responses to PPI in vivo. Indeed, in mice with spontaneous onset of autoimmune diabetes, CD8 T cells together with CD4 $\mathrm{T}$ cells are required for diabetes to occur [40], and both CD8 T-cell subsets, CD45RA ${ }^{+}$(effector) and $\mathrm{CD}^{2} 5 \mathrm{RA}^{-}$(memory), have been shown to secrete high amounts of IFN $\gamma$ and TNF $\alpha$ [41].

In our study cytokine responses in $\mathrm{Ab}+$ subjects had no IL-5 response at all in PBMC and both Th subsets. In contrast, in Type 1 diabetic patients treated with exogenous insulin for a median duration of 6 months naive and recently activated cells had a marked increase in IL-5, but memory cells did not. Interestingly, a recent study described new CD4+ regulatory $\mathrm{T}$ cells in NOD mice, which were generated by immunisation with pathogenic GAD65 $5_{524-543}$ peptide producing high levels of IL-5 and IFN $\gamma$ [42]. Also IL- 5 has been reported to be indicative of specific tolerance induction and immune deviation after nasal administration of GAD65 peptides in NOD mice [43].

Overall, our study shows that in subjects with an increased genetic risk of Type 1 diabetes immune responses to PPI peptides are vigorous. These are masked in unsorted PBMC largely due to the contribution of different cell types. In early stages of naturally occurring islet autoimmunity ( $\mathrm{Ab}+$ individuals) a massive increase in peripheral cytokine levels is present (except IL-5), which could not be detected in sorted Th-cell subsets. This indicates a contribution of cell types other than CD4+ cells. In Th-cell subsets of $\mathrm{Ab}+$ subjects low cytokine levels of predominantly $\mathrm{Th} 2 / \mathrm{Tr}$ phenotype and increased proliferation in response to C13-29 and B11-27 are present. After cessation of insulitis and exposure to exogenous insulin (Type 1 diabetic patients) an increase in IFN $\gamma, \mathrm{TNF} \alpha$, IL-5 and IL-10 levels and shift towards Th0 and Th2/Tr type of responses occur, accompanied by increased proliferation in response to B1-16. Although these specific differences could be due to the natural course of the disease, they could be the consequence of exogenous insulin treatment. It has been shown that insulin can modify T-cell autoimmunity in experimental models of Type 1 diabetes [44, 45] and in humans [6].

Together our results support the hypothesis that human Type 1 diabetes is not exclusively associated with Th1-mediated autoimmunity, and that Th1 and Th2 cells, as well as their respective mediators participate and cooperate in pancreatic islet beta-cell destruction (protection). This indicates that different cell subsets are activated in naturally occurring islet autoimmunity (Ab+ subjects) compared to insulin-treated Type 1 diabetic patients or disease-control subjects. Whether whole antigen or peptide epitope therapy before the onset of diabetes can induce non-destructive or protective T-cell subsets is not clear.

Acknowledgements. This work was supported by grants from the German Research Foundation (SFB 518 to I. DurinovicBelló, W. Karges and B.O. Boehm, and GRK460 studentship to S. Rosinger), the Eli Lilly Foundation International (to I. Durinovic-Belló), German Diabetes Foundation and Foundation The Diabetic Child (to I. Durinovic-Belló), and the German Diabetes Association (to I. Durinovic-Belló and S. Rosinger). We thank Dr. G. Seipke (Aventis, Frankfurt, Germany) and E. Lilly Company (Bad Homburg, Germany) for supplying us with insulin and proinsulin, C. Löliger (University Hospital Eppendorf, Hamburg, Germany) for HLA typing, and H.-J. Schreckling, B. Feldmann and M. Kuhn-Halder for clinical care of the patients.

\section{References}

1. Bohmer K, Keilacker H, Kuglin B et al. (1991) Proinsulin autoantibodies are more closely associated with Type 1 (insulin-dependent) diabetes mellitus than insulin autoantibodies. Diabetologia 34:830-834

2. Yu L, Robles DT, Abiru N et al. (2000) Early expression of antiinsulin autoantibodies of humans and the NOD mouse: evidence for early determination of subsequent diabetes. Proc Natl Acad Sci USA 97:1701-1706

3. Keller RJ (1990) Cellular immunity to human insulin in individuals at high risk for the development of type I diabetes mellitus. J Autoimmun 3:321-327

4. Durinovic-Belló I, Hummel M, Ziegler AG (1996) Cellular immune response to diverse islet cell antigens in IDDM. Diabetes 45:795-800

5. Petersen LD, Duinkerken G, Bruining GJ, Lier RA van, Vries RR de, Roep BO (1996) Increased numbers of in vivo activated $\mathrm{T}$ cells in patients with recent onset insulindependent diabetes mellitus. J Autoimmun 9:731-737 
6. Schloot NC, Roep BO, Wegmann D et al. (1997) Altered immune response to insulin in newly diagnosed compared to insulin-treated diabetic patients and healthy control subjects. Diabetologia 40:564-572

7. Schloot NC, Willemen S, Duinkerken G, Vries RR de, Roep BO (1998) Cloned T cells from a recent onset IDDM patient reactive with insulin B-chain. J Autoimmun 11:169175

8. Naquet P, Ellis J, Tibensky D et al. (1988) T cell autoreactivity to insulin in diabetic and related non-diabetic individuals. J Immunol 140:2569-2578

9. Durinovic-Belló I, Boehm BO, Ziegler AG (2002) Predominantly recognized proinsulin $\mathrm{T}$ helper cell epitopes in individuals with and without islet cell autoimmunity. J Autoimmun 18:55-66

10. Ilonen J, Surcel HM, Kaar ML (1991) Abnormalities within CD4 and CD8 T lymphocytes subsets in Type 1 (insulindependent) diabetes. Clin Exp Immunol 85:278-281

11. Peakman M, Alviggi L, Hussain MJ et al. (1994) Increased expression of T-cell markers of immunological memory associated with protection from type I diabetes. A study of identical twins. Diabetes 43:712-717

12. Smerdon RA, Peakman M, Hussain MJ et al. (1993) Increase in simultaneous coexpression of naive and memory lymphocyte markers at diagnosis of IDDM. Diabetes 42:127-133

13. Peterson LD, Keur M van der, Vries RR de, Roep BO (1999) Autoreactive and immunoregulatory T-cell subsets in insulin-dependent diabetes mellitus. Diabetologia 42:443-449

14. Sallusto F, Lenig D, Forster R, Lipp M, Lanzavecchia A (1999) Two subsets of memory $\mathrm{T}$ lymphocytes with distinct homing potentials and effector functions. Nature 401:708-712

15. Liblau RS, Singer SM, McDevitt HO (1995) Th1 and Th2 CD4+ $\mathrm{T}$ cells in the pathogenesis of organ-specific autoimmune diseases. Immunol Today 16:34-38

16. Alleva DG, Crowe PD, Jin L et al. (2001) A disease-associated cellular immune response in Type 1 diabetics to an immunodominant epitope of insulin. J Clin Invest 107:173-180

17. Strebelow M, Schlosser M, Ziegler B, Rjasanowski I, Ziegler M (1999) Karlsburg Type I diabetes risk study of a general population: frequencies and interactions of the four major Type I diabetes-associated autoantibodies studied in 9419 schoolchildren. Diabetologia 42:661670

18. Bingley PJ, Christie MR, Bonifacio E et al. (1994) Combined analysis of autoantibodies improves prediction of IDDM in islet cell antibody-positive relatives. Diabetes 43:1304-1310

19. Verge CF, Gianani R, Kawasaki E et al. (1996) Prediction of type I diabetes in first-degree relatives using a combination of insulin, GAD, and ICA512bdc/IA-2 autoantibodies. Diabetes 45:926-933

20. Erlich H, Bugawan T, Begovich AB et al. (1991) HLA-DR, DQ and DP typing using PCR amplification and immobilized probes. Eur J Immunogenet 18:33-55

21. Schlosser M, Strebelow M, Wassmuth R et al. (2002) The Karlsburg Type 1 diabetes risk study of a normal schoolchild population: association of beta-cell autoantibodies and human leukocyte antigen-DQB1 alleles in antibody-positive individuals. J Clin Endocrinol Metab 87:2254-2261

22. Williams AJ, Bingley PJ, Bonifacio E, Palmer JP, Gale EA (1997) A novel micro-assay for insulin autoantibodies. J Autoimmun 10:473-478
23. Durinovic-Belló I, Steinle A, Ziegler AG, Schendel DJ (1994) HLA-DQ-restricted, islet-specific T-cell clones of a type I diabetic patient. T-cell receptor sequence similarities to insulitis-inducing T-cells of nonobese diabetic mice. Diabetes 43:1318-1325

24. Peakman M, Tree TI, Endl J, Endert P van, Atkinson MA, Roep BO (2001) Characterization of preparations of GAD65, proinsulin, and the islet tyrosine phosphatase IA-2 for use in detection of autoreactive T-Cells in Type 1 diabetes: report of phase II of the Second International Immunology of Diabetes Society Workshop for Standardization of T-cell Assays in Type 1 diabetes. Diabetes 50:17491754

25. She JX, Ellis TM, Wilson SB et al. (1999) Heterophile antibodies segregate in families and are associated with protection from Type 1 diabetes. Proc Natl Acad Sci USA 96:8116-8119

26. Bacchetta R, Sartirana C, Levings MK, Bordignon C, Narula S, Roncarolo MG (2002) Growth and expansion of human $\mathrm{T}$ regulatory Type 1 cells are independent from TCR activation but require exogenous cytokines. Eur J Immunol 32:2237-2245

27. Maron R, Melican NS, Weiner HL (1999) Regulatory Th2-type $T$ cell lines against insulin and GAD peptides derived from orally- and nasally-treated NOD mice suppress diabetes. J Autoimmun 12:251-258

28. Tian J, Lehmann PV, Kaufman DL (1997) Determinant spreading of $\mathrm{T}$ helper cell 2 (Th2) responses to pancreatic islet autoantigens. J Exp Med 186:2039-2043

29. Ellis T, Jodoin E, Ottendorfer E et al. (1999) Cellular immune responses against proinsulin: no evidence for enhanced reactivity in individuals with IDDM. Diabetes 48:299-303

30. Congia M, Patel S, Cope AP, De Virgiliis S, Sonderstrup G (1998) $\mathrm{T}$ cell epitopes of insulin defined in HLA-DR4 transgenic mice are derived from preproinsulin and proinsulin. Proc Natl Acad Sci USA 95:3833-3838

31. Daniel D, Gill RG, Schloot N, Wegmann D (1995) Epitope specificity, cytokine production profile and diabetogenic activity of insulin-specific T cell clones isolated from NOD mice. Eur J Immunol 25:1056-1062

32. Walter M, Berg H, Northemann W (1994) Mapping of antigenic epitopes within the recombinant human preproinsulin related to insulin-dependent diabetes mellitus. J Clin Lab Anal 8:163-166

33. Berg H, Walter M, Mauch L, Seissler J, Northemann W (1993) Recombinant human preproinsulin. Expression, purification and reaction with insulin autoantibodies in sera from patients with insulin-dependent diabetes mellitus. J Immunol Methods 164:221-231

34. Kwok WW, Nepom GT, Raymond FC (1995) HLA-DQ polymorphisms are highly selective for peptide binding interactions. J Immunol 155:2468-2476

35. Geluk A, Meijgaarden KE van, Schloot NC, Drijfhout JW, Ottenhoff TH, Roep BO (1998) HLA-DR binding analysis of peptides from islet antigens in IDDM. Diabetes 47:15941601

36. Castano L, Ziegler AG, Ziegler R, Shoelson S, Eisenbarth GS (1993) Characterization of insulin autoantibodies in relatives of patients with type I diabetes. Diabetes 42:1202-1209

37. Ziegler AG, Standl E, Albert E, Mehnert H (1991) HLAassociated insulin autoantibody formation in newly diagnosed type I diabetic patients. Diabetes 40:1146-1149

38. Ziegler R, Alper CA, Awdeh ZL et al. (1991) Specific association of HLA-DR4 with increased prevalence and level of insulin autoantibodies in first-degree relatives of patients with type I diabetes. Diabetes 40:709-714 
39. Brooks-Worrell B, Gersuk VH, Greenbaum C, Palmer JP (2001) Intermolecular antigen spreading occurs during the preclinical period of human Type 1 diabetes. J Immunol 166:5265-5270

40. Miller BJ, Appel MC, O’Neil JJ, Wicker LS (1988) Both the Lyt-2+ and L3T4+ T cell subsets are required for the transfer of diabetes in nonobese diabetic mice. J Immunol 140:52-58

41. Hamann D, Baars PA, Rep MH et al. (1997) Phenotypic and functional separation of memory and effector human CD8+ T cells. J Exp Med 186:1407-1418

42. Quinn A, McInerney B, Reich EP, Kim O, Jensen KP, Sercarz EE (2001) Regulatory and effector CD4 T cells in nonobese diabetic mice recognize overlapping determi- nants on glutamic acid decarboxylase and use distinct $\mathrm{V}$ beta genes. J Immunol 166:2982-2991

43. Tian J, Atkinson MA, Clare-Salzler M et al. (1996) Nasal administration of glutamate decarboxylase (GAD65) peptides induces Th2 responses and prevents murine insulindependent diabetes. J Exp Med 183:1561-1567

44. Tian J, Chau C, Kaufman DL (1998) Insulin selectively primes Th2 responses and induces regulatory tolerance to insulin in pre-diabetic mice. Diabetologia 41:237240

45. Karges W, Pechhold K, Al-Dahouk S et al. (2002) Induction of autoimmune diabetes through insulin (but not GAD65) DNA vaccination in nonobese diabetic and in RIP-B7.1 mice. Diabetes 51:3237-3244 